Nevada

Environmental

Restoration

Project

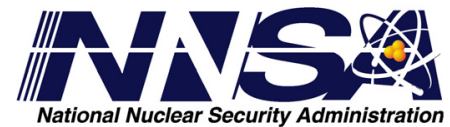

\title{
Addendum to the Closure Report for Corrective Action Unit 404: Roller Coaster Lagoons and Trench, Tonopah Test Range, Nevada
}

Controlled Copy No.:

Revision No.: 0

October 2008

Approved for public release; further dissemination unlimited.

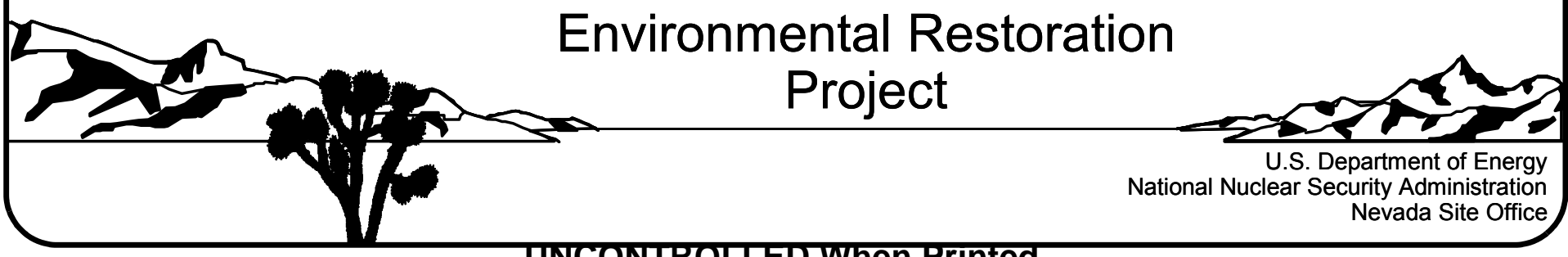


Available for public sale, in paper, from:

U.S. Department of Commerce

National Technical Information Service

5285 Port Royal Road

Springfield, VA 22161

Phone: 800.553 .6847

Fax: 703.605.6900

Email: orders@ntis.gov

Online ordering: http://www.ntis.gov/ordering.htm

Available electronically at $\underline{h t p: / / w w w . o s t i . g o v / b r i d g e ~}$

Available for a processing fee to U.S. Department of Energy and its contractors, in paper, from:

U.S. Department of Energy

Office of Scientific and Technical Information

P.O. Box 62

Oak Ridge, TN 37831-0062

Phone: 865.576 .8401

Fax: 865.576.5728

Email: reports@adonis.osti.gov

Reference herein to any specific commercial product, process, or service by trade name, trademark, manufacturer, or otherwise, does not necessarily constitute or imply its endorsement, recommendation, or favoring by the United States Government or any agency thereof or its contractors or subcontractors. 


\title{
ADDENDUM TO THE CLOSURE REPORT FOR CORRECTIVE ACTION UNIT 404: ROLLER COASTER LAGOONS AND TRENCH, TONOPAH TEST RANGE, NEVADA
}

\author{
U.S. Department of Energy \\ National Nuclear Security Administration \\ Nevada Site Office \\ Las Vegas, Nevada
}

Controlled Copy No.:

Revision No.: 0

October 2008

Approved for public release; further dissemination unlimited. 
Addendum to the Closure Report for Modification of the Use Restriction

This document constitutes an addendum to the September 1998, Closure Report for Corrective Action Unit 404: Roller Coaster Lagoons and Trench, Tonopah Test Range, Nevada as described in the document Recommendations and Justifications for Modifications for Use Restrictions Established under the U.S. Department of Energy, National Nuclear Security Administration Nevada Site Office Federal Facility Agreement and Consent Order (UR Modification document) dated February 2008. The UR Modification document was approved by NDEP on February 26, 2008. The approval of the UR Modification document constituted approval of each of the recommended UR modifications. In conformance with the UR Modification document, this addendum consists of:

- This cover page that refers the reader to the UR Modification document for additional information

- The cover and signature pages of the UR Modification document

- The NDEP approval letter

- The corresponding section of the UR Modification document

This addendum provides the documentation justifying the cancellation of the URs for:

- CAS TA-03-001-TARC Roller Coaster Lagoons

- CAS TA-21-001-TARC Roller Coaster N. Disposal Trench

These URs were established as part of Federal Facility Agreement and Consent Order (FFACO) corrective actions and were based on the presence of contaminants at concentrations greater than the action levels established at the time of the initial investigation (FFACO, 1996; as amended August 2006).

Since these URs were established, practices and procedures relating to the implementation of risk-based corrective actions (RBCA) have changed. Therefore, these URs were re-evaluated against the current RBCA criteria as defined in the Industrial Sites Project Establishment of Final Action Levels (NNSA/NSO, 2006c). This re-evaluation consisted of comparing the original data (used to define the need for the URs) to risk-based final action levels (FALs) developed using the current Industrial Sites RBCA process.

The re-evaluation resulted in a recommendation to modify these URs to administrative URs. Administrative URs differ from standard URs in that they do not require onsite postings (i.e., signs) or other physical barriers (e.g., fencing, monuments), and they do not require periodic inspections (see Section 6.2 of the Industrial Sites Project Establishment of Final Action Levels [NNSA/NSO, 2006c]). These Administrative URs were based on a "Remote Work Sites" future land use scenario that was used to calculate the FAL. The administrative UR will protect workers from an exposure exceeding that used in the calculation of the FAL (i.e., 336 hours per year). Any proposed activity within these use restricted areas that would potentially cause an exposure exceeding this exposure limit would require approval from the Nevada Division of Environmental Protection (NDEP). 
Requirements for inspecting and maintaining these URs will be canceled, and the postings and signage at each site will be removed. Fencing and posting may be present at these sites that are unrelated to the FFACO URs such as for radiological control purposes as required by the NV/YMP Radiological Control Manual (NNSA/NSO, 2004f). This modification will not affect or modify any non-FFACO requirements for fencing, posting, or monitoring at these sites. 
Nevada

Environmental

Restoration

Project

Recommendations and Justifications for Modifications for Use Restrictions Established under the U.S. Department of Energy, National Nuclear Security Administration Nevada Site Office

Federal Facility Agreement and Consent Order

Controlled Copy No.:

Revision No.: 0

February 2008

Approved for public release; further dissemination unlimited.

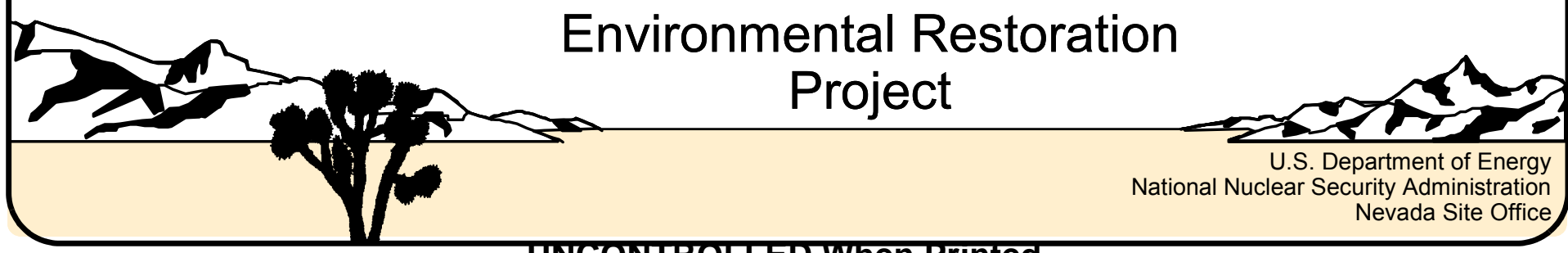


Recommendations and Justifications for Modifications for Use Restrictions Established under the U.S. Department of Energy, National Nuclear Security Administration Nevada Site Office Federal Facility Agreement and Consent Order

Approved by: /s/ Kevin J. Cabble

Date: $02 / 05 / 2008$

Kevin J. Cabble

Federal Sub-Project Director

Industrial Sites Sub-Project

Approved by:

/s/ John B. Jones

Date: $02 / 04 / 2008$

John B. Jones

Acting Federal Project Director

Environmental Restoration Project 
February 26, 2008

John B. Jones

Acting Federal Project Director

Environmental Restoration Project

National Nuclear Security Administration

Nevada Site Office

P. O. Box 98518

Las Vegas, NV 89193-8518

RE: Approval of Recommendations and Justifications for Modifications for Use Restrictions

Established under the U.S. Department of Energy, National Nuclear Security Administration, Nevada Site Office Federal Facility Agreement and Consent Order

Dear Mr. Jones:

The Nevada Division of Environmental Protection, Bureau of Federal Facilities (NDEP) staff has received and reviewed the February 2008 final report for Recommendations and Justifications for Modifications for Use Restrictions Established under the U.S. Department of Energy, National Nuclear Security Administration, Nevada Site Office. The NDEP approves the requested changes to the previously agreed upon use restrictions for those Corrective Action Sites (CASs) as described in the report.

Address any questions regarding this matter to either Ted Zaferatos at (702) 486-2850, ext. 234 , or me at (702) 486-2850, ext. 231.

Sincerely

\section{/s/ Tim Murphy}

\section{T.H. Murphy}

Chief

Bureau of Federal Facilities

$\mathrm{TZ}$

cc: $\quad$ E.F. DiSanza, WMP, NNSA/NSO

FFACO Group, PSG, NNSAINSO, Las Vegas, NV

David C. Loewer, DTRAVCXT1, M/S 645, Mercury, NV

W.R. Griffin, SNJV/DTRA, M/S 645, Mercury, NV

T.A. Thiele, NSTec, Las Vegas, NV

R.F. Boehlecke, SNJV, Las Vegas, NV

K. J. Cabble, ERP, NNSANSO, Las Vegas, NV

John Wong. Jeff MacDougall, Dennis Nicodemus, NDEP Las Vegas, NV 


\subsection{CAU 404, CAS TA-03-001-TARC - Roller Coaster Lagoons, and TA-21-001-TARC - Roller Coaster N. Disposal Trench}

\subsection{CAS Descriptions}

The CAU consists of two separate areas: CAS TA-03-001-TARC, Roller Coaster Lagoons, and CAS TA-21-001-TARC, Roller Coaster N. Disposal Trench. Both CASs are co-located approximately $4.3 \mathrm{mi}$ south of Area 3 along the Main Road South on the Tonopah Test Range (TTR). Associated with the CAU is an additional area where a small spill occurred during Voluntary Corrective Action (VCA) activities (DOE/NV, 1996).

The Roller Coaster Lagoons site consists of two large unlined sewage lagoons that received liquid sanitary wastes from the Operation Roller Coaster man camp. The man camp supported up to 600 people for approximately two months in 1963. The sanitary sewer system is approximately 120 by 75 by $10 \mathrm{ft}$. Subsequent to Operation Roller Coaster, the lagoons received debris from construction and range cleanup activities conducted on the TTR (DOE/NV, 1996).

The North Disposal Trench, located north of the eastern-most lagoon, was installed in 1963 to receive solid waste and construction debris from the Operation Roller Coaster man camp.

Subsequent to Operation Roller Coaster, the trench continued to receive construction debris and range cleanup debris (including ordnance) from Sandia National Laboratories (SNL) and other operators. The trench is approximately 100 by 12 by $10 \mathrm{ft}$ (DOE/NV, 1996).

A VCA operation removed ordnance and other debris from the two lagoons and trench. The debris and waste was segregated into: (1) recyclable ordnance and debris, (2) nonrecyclable debris, (3) hazardous waste, (4) suspected asbestos-containing materials, and (5) hydrocarbon-contaminated material. All items removed from the lagoons and trench, were screened for radiological contamination with handheld instruments and radiation swipes. No radiological contamination was detected (DOE/NV, 1996).

The North Disposal Trench (CAS TA-21-001-TARC) was clean closed by removal and disposal of the debris and backfilling the pit to grade (DOE/NV, 1998a).

\subsection{Current Use Restriction Description}

The future use of any land affected by this UR is restricted from any DOE or Air Force activity that may alter or modify the containment control, as approved by the state and identified in the 
CAU CR or other CAU documentation, unless appropriate concurrence is obtained in advance. The monitoring will consist of biannual visual inspections of:

- The cover for condition (e.g., subsidence, significant erosion unauthorized excavation) and plant development.

- The fence and signs to determine whether repairs are required.

Nonscheduled inspections may also be required after severe weather events such as heavy rainfall, flash flooding, and high winds. Any identified maintenance and repair requirements will be remedied within 90 days of discovery and documented in writing at the time of repair. Monitoring of the vegetative cover will be conducted during the first, third, and fifth year after revegetation. Monitoring during the first year will determine whether germination of seeded plant species has occurred. By the third year, plant establishment will be evaluated. By the fifth year, long-term survival can be predicted. Concurrently, wildlife use of the site will be evaluated with the objective of determining whether burrowing animals have moved onto the site and to what depth they might be expected to penetrate the cover. The erosion condition of the soil will be evaluated using a qualitative erosion condition classification developed by the Bureau of Land Management. Information gathered will be compared to natural conditions and will be used in assessing whether or not remedial action is necessary so that a viable vegetative cover is established (DOE/NV, 1998a).

It should be noted that the UR description includes a comment that the N. Disposal Trench was clean closed. The N. Disposal Trench is not included in the UR boundary.

\subsection{Basis for Current Use Restriction}

Samples from this CAU were analyzed for VOCs, SVOCs, RCRA metals, TPH, and pesticides. Contaminant levels were below PALs at the N. Disposal Trench CAS; therefore, it is not included in the UR boundary (DOE/NV, 1997). In both the East and West Lagoons, dichlorodiphenyl-dichlorethylene (DDE), dichlorodiphenyl-trichloroethane (DDT), and dichlorodiphenyl-dichloroethane (DDD) concentrations were identified in the surface soil samples above residential PRGs. In the West Lagoon, DDE and DDT concentrations exceeded industrial PRGs.

Table 23-1 contains analytical results of all COCs at CAU 404 that are the basis for the current UR. The sample matrix for all samples is soil. 
Table 23-1

Sample Results for COCs at CAU 404

Used To Establish Current Use Restriction

\begin{tabular}{|c|c|c|c|c|}
\hline \multirow{5}{*}{ Sample ID } & \multirow{5}{*}{ Lagoon } & DDD & DDE & DDT \\
\hline & & \multicolumn{3}{|c|}{ Residential Soil PRGs } \\
\hline & & $1,851 \mu \mathrm{g} / \mathrm{kg}$ & $1,307 \mu \mathrm{g} / \mathrm{kg}$ & $1,307 \mu \mathrm{g} / \mathrm{kg}$ \\
\hline & & \multicolumn{3}{|c|}{ Industrial Soil PRGs } \\
\hline & & $7,948 \mu \mathrm{g} / \mathrm{kg}$ & $5,610 \mu \mathrm{g} / \mathrm{kg}$ & $5,610 \mu \mathrm{g} / \mathrm{kg}$ \\
\hline TTR00084 & West & -- & 2,200 & 2,500 \\
\hline TTR00087 & West & 3,800 & 3,500 & 9,900 \\
\hline TTR00095 & West & 2,300 & 8,400 & 7,900 \\
\hline TTR00113 & West & 5,400 & 15,000 & 14,000 \\
\hline TTR00076 & East & -- & -- & 1,900 \\
\hline TTR00077 & East & -- & 1,600 & 2,600 \\
\hline \multicolumn{3}{|c|}{$\begin{array}{l}\text { DDD = Dichlorodiphenyl-dichloroethane } \\
\text { DDE = Dichlorodiphenyl-dichlorethylene } \\
\text { DDT = Dichlorodiphenyl-trichloroethane }\end{array}$} & \multicolumn{2}{|c|}{$\begin{array}{l}\text { ID = Identification } \\
\text { PRG = Preliminary remediation goal } \\
\mu \mathrm{g} / \mathrm{kg}=\text { Micrograms per kilogram }\end{array}$} \\
\hline \multicolumn{5}{|c|}{$--=$ No detects above action levels } \\
\hline
\end{tabular}

\subsection{Basis for Use Restriction Modification}

The revised FALs for DDE, DDT, and DDD as listed in Table 20-2 were established using the Tier 2-based FAL process as presented in Section 2.2.2. These FALs were calculated using the Remote Work Area site-specific exposure scenario. This scenario assumes that a worker will be exposed to the site contaminants for 336 hours per year for 25 years (a total exposure equivalent of 1,050 work days). This exposure scenario is for remote work sites that are not occupied during normal work assignments but where workers may occasionally be sent to perform work (NNSA/NSO, 2006c). Because CAS TA-03-001-TARC, Roller Coaster Lagoons, and CAS TA-21-001-TARC, Roller Coaster N. Disposal Trench, are both located in an inactive area approximately $4.3 \mathrm{mi}$ south of any industrial type sites (Area 3 ), no current or foreseeable future activities would cause any worker to be exposed to this site for a period of time exceeding that assumed in the remote work area scenario (i.e., 336 hours per year for 25 years).

The UR modification would be to remove CAS TA-21-001-TARC, Roller Coaster N. Disposal Trench, from the UR and to implement an administrative UR for the East and West Lagoons as described in Section 2.0. This administrative UR would restrict any activity that would result in any worker being within the UR boundary for a lifetime-duration of more than 1,050 total workdays. 
Table 23-2 presents the sample results that are the basis for the current UR and demonstrate that none exceed the revised FALs (based on a Remote Work Area land use scenario).

Table 23-2

Revised Final Action Levels for CAU 404

\begin{tabular}{||c|c|c|c|c|}
\hline \multirow{2}{*}{ Sample ID } & \multirow{2}{*}{ Lagoon } & DDD & DDE & DDT \\
\cline { 3 - 5 } & & $\begin{array}{c}\text { Revised FALs } \\
\mathbf{3 3 , 9 0 0} \mathbf{~} \mathbf{g} / \mathbf{k g}\end{array}$ & $\begin{array}{c}\text { Revised FALs } \\
\mathbf{2 3 , 9 0 0} \mathbf{~ g / / k g}\end{array}$ & $\begin{array}{c}\text { Revised FALs } \\
\mathbf{2 1 , 4 0 0} \mathbf{~ g / / k g}\end{array}$ \\
\hline \hline TTR00084 & West & -- & 2,200 & 2,500 \\
\hline TTR00087 & West & 3,800 & 3,500 & 9,900 \\
\hline TTR00095 & West & 2,300 & 8,400 & 7,900 \\
\hline TTR00113 & West & 5,400 & 15,000 & 14,000 \\
\hline TTR00076 & East & -- & -- & 1,900 \\
\hline TTR00077 & East & - & 1,600 & 2,600 \\
\hline
\end{tabular}

DDD = Dichlorodiphenyl-dichloroethane

ID = Identification

DDE = Dichlorodiphenyl-dichlorethylene

$\mathrm{FAL}=$ Final action level

DDT = Dichlorodiphenyl-trichloroethane

$\mu \mathrm{g} / \mathrm{kg}=$ Micrograms per kilogram

$--=$ No detects above original action levels

\subsection{Proposed Modification}

Implement an administrative UR for the East and West Lagoons as described in Section 2.0 restricting any activity that would result in any worker being within the UR boundary for a lifetime-duration of more than 1,050 total work days. Remove all fencing and postings as well as inspection and maintenance requirements. Remove the N. Disposal Trench from any UR because it was clean closed and contaminant levels were below PALs. 


\section{References}

DOE/NV, see U.S. Department of Energy, Nevada Operations Office.

FFACO, see Federal Facility Agreement and Consent Order.

Federal Facility Agreement and Consent Order. 1996 (as amended). Agreed to by the State of Nevada; U.S. Department of Energy, Environmental Management; U.S. Department of Defense; and U.S. Department of Energy, Legacy Management.

NNSA/NSO, see U.S. Department of Energy, National Nuclear Security Administration Nevada Site Office.

U.S. Department of Energy, National Nuclear Security Administration Nevada Site Office. 2004f. NV/YMP Radiological Control Manual, DOE/NV--11718-079, Rev. 5. Prepared by Bechtel Nevada. Las Vegas, NV.

U.S. Department of Energy, National Nuclear Security Administration Nevada Site Office. 2006c. Industrial Sites Project Establishment of Final Action Levels, Rev. 0, DOE/NV--1107. Las Vegas, NV.

U.S. Department of Energy, Nevada Operations Office. 1996. Corrective Action Investigation Plan: Roller Coaster Lagoons and North Disposal Trench, Tonopah Test Range, Nevada, Rev. 0, DOE/NV--425. June. Las Vegas, NV.

U.S. Department of Energy, Nevada Operations Office. 1997. Corrective Action Decision Document for the Roller Coaster Lagoons and North Disposal Trench (Corrective Action Unit No. 404), Rev. 0, DOE/NV--474. March. Las Vegas, NV.

U.S. Department of Energy, Nevada Operations Office. 1998a. Closure Report for Corrective Action Unit 404: Roller Coaster Sewage Lagoons and North Disposal Trench, Tonopah Test Range, Nevada, Rev. 0, DOE/NV/11718-187. September. Las Vegas, NV. 


\section{Library Distribution List}

\section{$\underline{\text { Copies }}$}

U.S. Department of Energy

National Nuclear Security Administration

Nevada Site Office

Technical Library

P.O. Box 98518, M/S 505

Las Vegas, NV 89193-8518

U.S. Department of Energy

Office of Scientific and Technical Information

P.O. Box 62

Oak Ridge, TN 37831-0062

Southern Nevada Public Reading Facility

c/o Nuclear Testing Archive

P.O. Box 98521, M/S 400

Las Vegas, NV 89193-8521

Manager, Northern Nevada FFACO

Public Reading Facility

c/o Nevada State Library \& Archives

100 N Stewart Street

Carson City, NV 89701-4285
1 (Uncontrolled, electronic copy)

1 (Uncontrolled, electronic copy)

2 (Uncontrolled, electronic copies)

1 (Uncontrolled, electronic copy) 